\title{
The supervision of information technology classrooms in Turkey: A nationwide survey
}

\author{
Salih Pasa Memisoglu \\ Abant Izzet Baysal University, Turkey
}

The purpose of this study was to identify how primary school supervisors carry out their roles concerning information and communications technology (ICT) based classrooms in public primary schools in Turkey. Data were collected via a questionnaire from 583 primary school supervisors working in 17 different provinces. Statistical programs were used to calculate descriptive statistics, frequencies and percentages for questionnaire items. The results of the study indicated that most supervisors were familiar with computers, but only used them at the 'medium' level, mostly for word processing, spreadsheets and drawing up reports on school visits. Almost all of the respondents sought to support the effective development of ICT based classrooms by examining teachers' plans, providing computer application opportunities for pupils, and helping school principals encourage and manage such undertakings. However, almost $50 \%$ of the supervisors indicated that they had no knowledge or understanding of e-portfolios, and that they had never received professional development or in service training in exploiting the ICT based classroom. As a result, they were unable to provide sufficient guidance to teachers. The paper concludes with recommendations for future action.

\section{Introduction}

From the Seljuk Era (1071-1299) until the Ottoman Empire (1299-1922), the state always had a significant role in the establishment and development of educational institutions in Anatolia. After the foundation of the Turkish Republic on 29 October 1923, article 87 of the newly adopted 1924 Constitution reiterated the need for compulsory and free primary education for all Turkish citizens in state schools (Akyüz, 2006) and ever since, there has been a rapid increase in the number of pupils, teachers and schools nationwide. In the school year 2004-2005, there were 10,291,352 pupils (47\% female) and 389,850 teachers (46\% female) in the nation's 34,261 public schools, 728 private schools and distance education school (MoNE, 2005). 
The Turkish public education system is highly centralised with all of its educational activities planned, organised and evaluated by the Ministry of National Education (MoNE) in the capital, Ankara. The supervision of education is carried out by two units; the Presidency of Supervision Board (PIB) based in Ankara, which supervises the Ministry's central units, provincial educational directorates, school districts and secondary schools on behalf of MoNE and prepares reports for government for the improvement of education, and the Presidency of Primary School Supervisors (PPSS), which is responsible for the professional development of primary school teachers and principals and supervision of schools and teaching at the provincial level.

\section{ICT Integration in the Turkish schools system}

ICT integration in Turkish primary schools began as part of the Basic Education Program (BEP). In August 1997, Parliament approved the new Basic Education Law (4306) which extended the duration of compulsory schooling from five to eight years and mandated improvements in the quality and relevance of basic education. The implementation of BEP has been facilitated by governmental funds, donations, loans from the World Bank and support from the European Commission. The main purpose of the $\mathrm{BEP}$ was to improve the quality of primary education by:

- Increasing compulsory schooling from 5 to 8 years (6-14 age range).

- Increasing primary school attendance from $86 \%$ to $100 \%$, and preschool attendance to $16 \%$.

- Reducing class size from greater than 40 , to 30 pupils.

- Building and equipping additional classrooms.

- Making foreign language learning compulsory.

- Revitalising the primary curriculum and pedagogy, with a focus on the learner rather than the teacher and the development of such skills as critical and creative thinking, researching, problem solving, communicating and utilising information technologies.

- Making all pupils and teachers computer literate.

In regard to the last point, MoNE states that a fundamental purpose of the Turkish education system is to prepare learners for an information society, and that the aim is to provide information technology and communications (ICT) classrooms and infrastructure in all public schools.

Phase 1 (1998-2003) of BEP saw:

- 3,188 ICT classrooms and infrastructure established in 2,802 schools.

- 6,513 televisions, 6,503 video recorders / players and 9,453 overhead projectors installed in 6,180 schools and 6,254 educational video cassette series and 6,254 film slide series purchased for 6,254 schools. 
- 1,500 notebook computers purchased for primary school supervisors.

- Projectors purchased for 6,255 primary schools within which the IT classrooms were established.

- 3,000 primary school supervisors, 25,000 primary school teachers and 2,058 computer coordinators given in-service training in ICT.

- 15,298 teachers in schools where ICT classrooms had been established attending basic and advanced ICT training programs.

- An ICT literacy handbook prepared and distributed to all schools.

- Educational CDs prepared and distributed to all schools.

- At least one computer coordinator appointed or designated in all schools with IT classrooms to act as change agents and train other teachers in ICT and computer assisted instruction (CAI).

- Training provided for the computer coordinators in hardware, operating systems, networking, authoring languages, programming languages and database administration.

Phase 2 has since been underway with broadly the same goals as Phase 1 but with MONE aiming to establish ICT classrooms in several thousand more primary schools, create an educational portal, train more supervisors, principals and teachers, develop and refurbish more schools in low income areas, develop preschool and special needs education, and provide ICT training and materials for educating children with special needs. In the 2005 Campaign for Supporting Computer Aided Education, 110,000 computer donations were granted to public schools by corporate providers and private citizens. A major World Bank loan helped to provide a further 294,000 computers in these schools. Between 2003 and 2005, ICT classrooms were established in 19,000 schools. In 2002, there was one computer between 164 pupils in these schools and by 2006, one computer for every 48 pupils. The current target is one computer per 35 pupils.

It is axiomatic that ICT should be used appropriately, effectively and in accord with MoNE's objectives for the curriculum and teaching and learning. However, despite heavy expenditure, a number of studies have indicated clearly that ICT is not being infused into classroom practice as intended (Özek, 2002; Sonar, 2002; Demiraslan \& Koçak-Usluel, 2004; Karagoz, 2004). According to Karagoz (2004) and Özdemir and Kılıç (2007), absence of supervision is one of the reasons for this. The role of the primary school supervisors in monitoring, evaluating progress, identifying problems, and providing advice and support is clearly critical in such an ambitious program, so let us examine the work of these personnel.

\section{Primary school supervisors}

Primary school supervisors are mainly graduates of education faculties and institutes and/or successful primary school teachers who have received 
special training in educational management and supervision (Saglamer, 2007). The Primary School Supervisors' Regulations require all such personnel to serve as assistant supervisors for three years, during which time they gain on the job experience and receive training in educational laws and regulations, supervision, consultancy, research and evaluation.

Every province has its own Directorate of Primary School Supervisors comprising a director, vice-directors, supervisors and assistant supervisors. This Directorate cooperates with the local education authorities in providing guidance, on the job training, supervision, mentoring and analysis of trends and needs. The Directorates also operate audit groups, which assess teachers' capacities and attitudes in accordance with Teacher Supervision Checklists and enable the supervisors to help teachers with their teaching methods, uses of teaching and learning resources and any problems they may face.

The duties of the supervisors are quite complex and demanding. They are expected to plan and arrange professional development meetings with teachers at the beginning and end of each semester, provide in service training, help teachers access and use new teaching and learning resources, provide guidance in pupils' developmental characteristics and their pedagogical implications and how to establish good relations with parents. They are required to help principals with their leadership, management and administrative skills and deal with any disciplinary problems arising in the schools. They are expected to have the ability to identify strengths and weaknesses in the current operations, determine needs and identify problems encountered by teachers and principals. And they are also expected to conduct research into the factors that affect the quality, productivity and cost effectiveness of education and suggest solutions to any problems that may be thrown up by these studies.

Nor are these supervisors simply responsible for the primary schools. Their duties also entail guidance and supervision of preschool and special education, apprenticeship and non-formal education institutions, sports, scouting offices and other activities. Each province is divided into subareas according to the number of schools and teachers, and each of these areas is accorded a supervision group. Each primary school supervisor is responsible for nearly 80 teachers.

MoNE emphasises that these supervisors are regarded as having an important role in helping schools integrate ICT in their classrooms and teaching and learning. To fulfill these expectations, supervisors need considerable knowledge and skills to motivate and guide the teachers in their uses of ICT (Gürer, 2005; Turan, 2002). This not only requires them to be computer literate (Akbaba-Altun, 2004) but also able to help teachers use 
computers and the Internet in teaching and learning (Oliva \& Pawlas, 1997) and in course design (Wiles \& Bondi, 2000). Even where classrooms are well equipped with ICT, Rutherford (2004) observes that it is unlikely that most teachers will be able to exploit the power of these tools without encouragement and support and so the first step toward the effective use of technology in classrooms should be fostering positive attitudes in teachers toward technology (Bozeman \& Hiatt, 1999; Bates \& Poole, 2003; Albirini, 2006). MoNE clearly recognises these points in suggesting that the primary school supervisors should:

- Be trained in word processing, spreadsheets and the use of the Internet and Web so that they have the knowledge and skills to supervise and advise teachers and principals in using the technology.

- Emphasise that computers are educational tools and promote their use for educational purposes.

- Be capable of providing guidance in educational applications of ICT in the classroom.

- Report on the operating conditions and utilisation of ICT classrooms.

- Monitor the uses of ICT by inspecting the pupils' e-portfolios or activity files (one of the innovations in the new curriculum was assessment by portfolio. Pupils are expected to enter their assignments and homework into computers so that these can be monitored by teachers and supervisors to observe improvements, identify problems and provide appropriate guidance to pupils and teachers).

Given these expectations, it was decided to research:

- The supervisors' experiences in using ICT.

- How the supervisors felt they benefited from using computers in their work.

- The expected and actual activities of the supervisors.

- How the supervisors encouraged the teachers to use ICT in the classroom.

\section{Method}

Primary school supervisors were surveyed by the use of a questionnaire comprising 20 items investigating the supervisors' experience of computers and use of ICT in the classroom. The director of primary school supervisors in each province helped with distribution and collection of the questionnaires. The instrument was completed by $75 \%$ of the supervisors $(n=583)$ in 17 provinces. In the data analyses a statistical program was used. Descriptive statistics methods were applied, and frequencies and percentages were computed. Table 1 provides a profile of the respondents. 
Table 1: Primary school supervisors profile $(\mathrm{n}=583)$

\begin{tabular}{|c|c|c|c|}
\hline \multirow{3}{*}{ Gender } & & $\mathrm{f}$ & $\%$ \\
\hline & Male & 551 & 94.6 \\
\hline & Female & 32 & 5.4 \\
\hline \multirow{7}{*}{$\begin{array}{l}\text { Teaching } \\
\text { experience } \\
\text { (years) }\end{array}$} & $1-5$ & 3 & 0.5 \\
\hline & $6-10$ & 3 & 0.5 \\
\hline & $11-15$ & 37 & 6.3 \\
\hline & $16-20$ & 83 & 14.2 \\
\hline & $21-25$ & 73 & 12.5 \\
\hline & $26-30$ & 141 & 24.1 \\
\hline & 31 and more & 243 & 41.6 \\
\hline \multirow{7}{*}{$\begin{array}{l}\text { Supervision } \\
\text { experience } \\
\text { (years) }\end{array}$} & $1-5$ & 49 & 8.4 \\
\hline & $6-10$ & 106 & 18.1 \\
\hline & $11-15$ & 205 & 35.1 \\
\hline & $16-20$ & 70 & 12.0 \\
\hline & $21-25$ & 80 & 13.7 \\
\hline & $26-30$ & 44 & 7.5 \\
\hline & 31 and more & 29 & 4.9 \\
\hline \multirow{4}{*}{$\begin{array}{l}\text { Education } \\
\text { level }\end{array}$} & 3 years high school & 121 & 20.7 \\
\hline & 4 years high school & 387 & 66.7 \\
\hline & Masters & 70 & 12.0 \\
\hline & PhD & 5 & 0.8 \\
\hline
\end{tabular}

\section{Findings}

\section{Supervisors' computer use levels and experience}

Table 2: Supervisors' computer use levels and experience $(n=583)$

\begin{tabular}{|c|c|c|c|}
\hline & Choices & $\mathrm{f}$ & $\%$ \\
\hline \multirow[t]{4}{*}{ Level of computer use } & Don't use & 13 & 2.2 \\
\hline & Beginner & 50 & 8.6 \\
\hline & Intermediate & 433 & 74.3 \\
\hline & Advanced & 87 & 14.9 \\
\hline \multirow{5}{*}{$\begin{array}{l}\text { Hours of in service training } \\
\text { related to using computing } \\
\text { tools }\end{array}$} & None & 16 & 2.7 \\
\hline & $1-3$ & 458 & 78.6 \\
\hline & $4-6$ & 97 & 16.6 \\
\hline & $7-10$ & 11 & 1.9 \\
\hline & 11 and more & 1 & 0.2 \\
\hline \multirow[t]{5}{*}{ Years of computer use } & Non-user & 15 & 2.6 \\
\hline & $1-3$ & 144 & 24.7 \\
\hline & $4-6$ & 265 & 45.5 \\
\hline & 7 or more & 157 & 26.9 \\
\hline & Missing & 2 & 0.3 \\
\hline \multirow{2}{*}{$\begin{array}{l}\text { Attended in service training } \\
\text { related to the ICT classroom }\end{array}$} & Yes & 97 & 16.6 \\
\hline & No & 486 & 83.3 \\
\hline
\end{tabular}


Table 2 shows that $2.2 \%$ of the supervisors reported that they don't use computers, $8.6 \%$ that they used computers only at a 'beginner' level, $74.3 \%$ that they used computers at a 'medium' level and $14.9 \%$ at an 'advanced' level. These findings confirm findings by Akbaba-Altun (2004). Those reporting that they never used computers had 31 or more years of service.

The findings also revealed that $2.7 \%$ of the supervisors had never undergone any in service training in ICT, while $78.6 \%$ had only undergone 1-3 hours of such training. The senior supervisors, 8 with seniority of 31 years or more, 3 with 11-15 years' seniority, 3 with 16-20 years' seniority and 3 with 26-30 years' seniority, had received no such training.

Fifteen $(2.6 \%)$ of the supervisors claimed to have never even used a computer, $45.5 \%$ to have been using computers for 4-6 years and $26.9 \%$ for 7-9 years. Analysing the seniority of those stating that they had never worked with computers, it was found that 9 had served for 31 years or more, 3 for 16-20 years, and 3 for 26-30 years.

Asked which software programs they used (the respondents could select more than one answer) it was found that the major application was word processing (96.6\%). Spreadsheets were used by $70.9 \%$ of supervisors, PowerPoint by $46.7 \%$ and email by a mere $12.2 \%$. These findings again support those of Akbaba-Altun (2004). In answer to the final question, only $16.6 \%$ of the supervisors indicated that they had received any in service training in using ICT in the classroom.

\section{Supervisors' levels of knowledge and use of ICT}

As shown in Table 3, the majority of supervisors, $63.6 \%$, described their level of knowledge and use of computer technology as 'medium'. Less than one fifth claimed to use their computers often and less than $1 \%$ to being 'advanced' in computer literacy or use. In regard to the Internet, about half of the supervisors described their knowledge level as 'medium' and only about $8 \%$ as 'advanced'. About a quarter of the respondents claimed to have no knowledge of the purposes of and provisions the ICT classrooms, $35 \%$ suggested that they had 'low' levels of knowledge in this area, 36.5\% rated their knowledge as 'medium', and only 3.1\% felt their knowledge was 'advanced'.

Only $33.7 \%$ of the supervisors felt that they had the knowledge to guide and support teachers experiencing problems in the ICT classrooms. About $78 \%$ of the supervisors rated their knowledge of educational applications of ICT as 'low' or 'medium'. 
Table 3: Supervisors' levels of knowledge and use of ICT and its educational applications $(n=583)$

\begin{tabular}{|l|l|c|c|}
\hline \multirow{4}{*}{$\begin{array}{l}\text { Knowledge and use of computer } \\
\text { technology }\end{array}$} & Low & f & $\%$ \\
\cline { 2 - 4 } & Medium & 371 & 63.6 \\
\cline { 2 - 4 } & Often & 111 & 19.0 \\
\cline { 2 - 4 } & Advanced & 5 & 0.9 \\
\hline Knowledge and use of the Internet & None & 48 & 8.3 \\
\cline { 2 - 4 } & Low & 196 & 33.6 \\
\cline { 2 - 4 } & Medium & 291 & 49.9 \\
\cline { 2 - 4 } & Advanced & 48 & 8.3 \\
\hline \multirow{4}{*}{$\begin{array}{l}\text { Knowledge of ICT classrooms } \\
\text { purposes and provisions }\end{array}$} & Non & 147 & 25.2 \\
\cline { 2 - 4 } & Low & 205 & 35.2 \\
\cline { 2 - 4 } & Medium & 213 & 36.5 \\
\cline { 2 - 4 } & Advanced & 18 & 3.1 \\
\hline $\begin{array}{l}\text { Knowledge in guidance and } \\
\text { support for teachers experiencing } \\
\text { problems in the ICT classrooms. }\end{array}$ & Yes & 196 & 33.7 \\
\cline { 2 - 4 } $\begin{array}{l}\text { Knowledge about educational } \\
\text { applications of ICT }\end{array}$ & No & 387 & 66.4 \\
\cline { 2 - 4 } & None & 31 & 5.3 \\
\cline { 2 - 4 } & Low & 160 & 27.4 \\
\cline { 2 - 4 } & Medium & 294 & 50.4 \\
\cline { 2 - 4 } & Advanced & 98 & 16.8 \\
\hline
\end{tabular}

\section{Supervisors' aims in using computers}

The supervisors were asked to note their aims in using computers (here again they could select more than one answer). As shown in Table 4, the supervisors used ICT mainly for their own work and personal development: $92 \%$ of supervisors used computers mostly for writing supervision, observation and research reports, almost $72 \%$ for gaining information through the Internet and other sources and 52\% for developing their computer literacy. Only 32\% appeared to use ICT in order to develop capacities in guiding teachers and pupils and supervising ICT classrooms.

Table 4: Supervisors' aims in using computers

\begin{tabular}{|l|c|c|}
\hline & $\mathrm{f}$ & $\%$ \\
\hline Writing supervision, observation, research reports & 561 & 96.2 \\
\hline Gaining information through the Internet and computer databases & 417 & 71.5 \\
\hline Improving their computer literacy skills & 305 & 52.3 \\
\hline Ability to guide teachers and pupils and supervise ICT classrooms & 187 & 32.1 \\
\hline Other & 29 & 0.5 \\
\hline
\end{tabular}

\section{Expected and actual performance of supervisory roles}

As Table 5 reveals, almost one fifth of the supervisors never, and almost two-thirds only sometimes, provided guidance in ICT classroom 
organisation and applications. Almost $70 \%$ of them stated that they sometimes intervened to help principals and teachers begin operating ICT classrooms, $47 \%$ that they identified problems in activating ICT classrooms and $62 \%$ that they attempted to diagnose and remedy the problems arising. While about $60 \%$ of the supervisors performed in their traditional roles of examining teachers' lesson plans and classroom observation, only just over half made any reference to the pupils' e-portfolios in judging processes and outcomes.

Table 5: Expected and actual performance of supervisory roles $(n=583)$

\begin{tabular}{|c|c|c|c|c|}
\hline Expected activities & \multicolumn{2}{|c|}{ Actual activities } & $\mathrm{f}$ & $\%$ \\
\hline \multirow{4}{*}{$\begin{array}{l}\text { Providing guidance } \\
\text { in ICT classroom } \\
\text { organisation and } \\
\text { applications }\end{array}$} & \multicolumn{2}{|l|}{ None } & 109 & 18.7 \\
\hline & \multicolumn{2}{|l|}{ Some } & 370 & 63.5 \\
\hline & \multicolumn{2}{|l|}{ Often } & 89 & 15.3 \\
\hline & \multicolumn{2}{|l|}{ No idea } & 15 & 2.6 \\
\hline \multirow[t]{3}{*}{$\begin{array}{l}\text { Reporting on } \\
\text { inactive ICT } \\
\text { classrooms }\end{array}$} & \multicolumn{2}{|c|}{$\begin{array}{l}\text { Encouraging and advising school principals and } \\
\text { teachers on how to activate inactive ICT } \\
\text { classrooms }\end{array}$} & 403 & 69.1 \\
\hline & \multicolumn{2}{|c|}{ Identifying problems in activating ICT classrooms } & 271 & 46.5 \\
\hline & \multicolumn{2}{|c|}{$\begin{array}{l}\text { Reporting and advising on problems in ICT } \\
\text { classrooms }\end{array}$} & 361 & 61.7 \\
\hline \multirow{8}{*}{$\begin{array}{l}\text { Undergoing in } \\
\text { service training to be } \\
\text { more effective in } \\
\text { guiding and } \\
\text { supervising } \\
\text { principals and } \\
\text { teachers in their } \\
\text { work in ICT } \\
\text { classrooms }\end{array}$} & \multirow[t]{2}{*}{ Word processing } & I use & 563 & 96.6 \\
\hline & & I don't use & 20 & 3.4 \\
\hline & \multirow{2}{*}{ Spreadsheets } & I use & 411 & 70.5 \\
\hline & & I don't use & 172 & 29.5 \\
\hline & \multirow[t]{2}{*}{ PowerPoint } & I use & 272 & 46.7 \\
\hline & & I don't use & 311 & 53.3 \\
\hline & \multirow[t]{2}{*}{ Email programs } & I use & 71 & 12.2 \\
\hline & & I don't use & 512 & 87.8 \\
\hline \multirow[t]{4}{*}{$\begin{array}{l}\text { Monitoring ICT } \\
\text { classrooms }\end{array}$} & \multicolumn{2}{|c|}{$\begin{array}{l}\text { Examining teachers' lesson plans and observing } \\
\text { teaching and learning }\end{array}$} & 349 & 59.9 \\
\hline & \multicolumn{2}{|c|}{ Examining educational outputs in ICT classrooms } & 129 & 22.1 \\
\hline & \multicolumn{2}{|c|}{ Asking pupils questions in ICT classrooms } & 104 & 17.8 \\
\hline & \multicolumn{2}{|c|}{ Assessing pupils' activities through e-portfolios } & 308 & 52.8 \\
\hline
\end{tabular}

\section{Conclusion}

With the introduction of the new primary curriculum, Turkish teachers are expected to implement more learner centred approaches and involve pupils in ICT based learning. However, it is not easy for these teachers to give up their traditional approaches. And while the system makes provision for computer coordinators in the schools, the experience and training of these coordinators is usually too limited for them to be champions for change, they tend to be primarily concerned with technological rather than pedagogical issues, and they often have to contend with heavy workloads, sometimes teaching in their subject areas 
as well, and a lack of support from the principals and supervisors (Özdemir \& Kılıç, 2007). It is also the case that supervisors only evaluate the coordinators' performance on the basis of their subject teaching and so, not surprisingly, they tend to pay greater attention to this than their coordinating and change agent roles (Akbaba-Altun, 2006).

This study exposes the fact that many of the primary school supervisors who are mandated to encourage, guide and support the educational use of ICT in the classroom lack the training, depth of understanding and body of experience to be able to address these issues. Those supervisors who have seniority of 31 years or more simply do not use computers and have never attended any ICT related in service training courses. Most of the remaining supervisors may use computers in support of their supervisory duties, observation of practice and provision, and research, but they are far less well-versed in educational applications of ICT. Very few of them have received any training in establishing and developing ICT based classrooms and the vast majority lack advanced knowledge and skills in uses of the technology, let alone understanding of the full potential of ICT in educational development. Many of the supervisors are apparently unfamiliar with the concept of e-portfolios, despite the expectation that they use these to monitor progress in ICT classroom development and pupils' learning.

It is of course possible to see extenuating circumstances for this state of affairs. The roles and duties of the supervisors are extensive, complex and demanding. There is ambivalence in their roles - they are required to be both 'inspectors', requiring accountability and conformity and 'professional facilitators', helping teachers with their problems and empowering them to do better. In many cases, rather than guiding ICT development in the classroom, helping teachers use computers for educational purposes and assisting principals in managing such a paradigm shift, they are fully occupied in checking and reporting on the kinds of improvements needed. They may be expected to be prime movers in activating ICT classrooms, but less than half of them have actually been able to start doing this. Some may give some encouragement to the principals and teachers, note some of the problems and offer some advice, but this is inadequate to achieve the levels and extent of change needed. Özdemir and Kılıç (2007) note that MoNE had prepared a checklist for the supervisors, but that this mainly focused on such minor matters as the cleanliness of the ICT classrooms and maintenance of the hardware and software. They reported that teachers said that the supervisers rarely visited their classrooms to observe what was going on and that most of their questions were about minor issues rather than the educational content 
and methodologies. They also found that many principals kept the ICT classrooms under lock and key to protect against theft, damage or improper use of the computers, printers, scanners, video equipment and multimedia software and despite instructions to this effect from MoNE, did not accord the title 'vice-principal' to the computer coordinators or give them time for their ICT duties.

In the light of all the above findings, the following conclusions may be drawn:

1. There is need for a significant change in the culture and organisation of primary school supervision to achieve the desired educational and technological development.

2. The supervisors are critical to success and need to become far more involved in the processes of change and assisting in overcoming any barriers that may arise, whether technological, organisational or pedagogical.

3. The supervisors also need to develop a whole range of new expertise that will enable them to advise on the hardware, software and courseware needs of schools and where and how to source these.

3. The supervisors' roles should change from monitoring and identifying inactivity and deficiencies to presenting contextualised and customised professional development programs for teachers and principals.

4. To fully and effectively engage in this work, the supervisors need far more extensive, in depth and rigorous in service training and hands on experience in curriculum change and educational technology.

5. Not all of this training needs to be face to face. The supervisors can be given timely and quality online training, information and opportunity to interact with colleagues and schools regardless of where they are stationed or their working circumstances. By using the same technologies and methodologies being advocated for the pupil's learning - email, wikis, curriculum resource web sites, etc, they can gain invaluable insights to pass on to teachers.

6. A 'train trainers' to gain a 'multiplier effect' within the teaching force is needed. Teachers are often more influenced by the advocacies, experiences and achievements of their colleagues than those of 'outside experts'. 
7. The computer coordinators also have a key role to play in training trainers and networking, so there should be close collaboration between the supervisors and coordinators, and criteria should be developed for evaluating the coordinators' performance in this regard and recognition and reward for this work.

Only through the adoption of such means can the fullest and most effective integration of ICT into education be achieved across the Turkish school system. Such an approach calls for inter-institutional and inter-sector collaboration. Colleges of education need to become active in training the primary school supervisors, computer coordinators, teachers and principals in how to use ICT technologies effectively in curriculum and pedagogy. Central and local governments need to develop ICT information and help services for the school system. In response to the needs and opportunities of the 'knowledge society', all of the educational providers need to constantly revise and renew their curricula and courses to prepare pupils for the 21st century and greater dependency upon ICT, and conduct further studies into how to use technology to the best educational effect and encourage and support such development in the nation's schools.

\section{Acknowledgements}

The author and AJET acknowledge with gratitude the assistance very kindly provided by Mr Colin Latchem, Open Learning Consultant, acting as an honorary associate editor for this issue.

\section{References}

Akbaba-Altun, S. (2004). Ilkogretim mufettislerinin bilgisayar kullanma duzeyleri ve amaclari. Paper presented at the annual meeting of Fifth Educational Technology Symposium, 24-26 November 2004, Sakarya, Turkey.

Akbaba-Altun, S. (2006). Complexity of integrating computer technologies in education in Turkey. Educational Technology and Society, 9(1), 176-187. http: / / www.ifets.info/journals/9_1/15.pdf

Akyuz, Y. (2006). Turk egitim tarihi. Ankara: Pegem A.

Albirini, A. (2006). Teachers' attitudes toward information and communication technologies: The case of Syrian EFL teachers. Computers $\mathcal{E}$ Education, 47(4), 373398.

Bates, A. W. and Poole, G. (2003). Effective teaching with technology in higher education. CA: Jossey-Bass.

Bozeman, W. C. \& Hiatt, L. (1999). Instructional technology: Administrative support and leadership. The AASA Professor, 23(1), 3-4. 
Demiraslan, Y. \& Koçak-Usluel, Y. (2004). Bilgi ve iletisim teknolojilerinin ogrenmeogretme surecine entegrasyonunda ogretmenlerin durumu. Paper presented at the annual meeting of Fifth Educational Technology Symposium, 24-26 November 2004, Sakarya, Turkey.

Gürer, M. D. (2005). Bilgi teknolojisi sinflarmda denetim. Unpublished master's thesis, Abant Izzet Baysal University, Bolu, Turkey.

Karagoz, I. (2004). Ilkogretim okulu mudurlerinin ve formator ogretmenlerinin bilgi teknolojisi siniflarinin kullanilmasina yonelik gorusleri. Unpublished master's thesis, Abant Izzet Baysal University, Bolu, Turkey.

MoNE (Ministry of National Education) (2005). 2004-2005 Statistical Data. (in Turkish) [viewed 2 May 2006] http:/ / sgb.meb.gov.tr/

Oliva, P. F. \& Pawlas, G. E. (1997). Supervision for today's schools. White Plains, NY: Longman.

Özdemir, S. \& Kılıç, E. (2007). Integrating information and communication technologies in the Turkish primary school system. British Journal of Educational Technology, 38(5), 907-916.

Ozek, I. (2002). Ilkogretim okullarinda bilgi teknolojisi siniflarinin degerlendirilmesi. Unpublished master's thesis. Afyon Kocatepe University, Afyon, Turkey.

Rutherford, J. (2004). Technology in the schools. Technology in Society, 26, 149-160.

Saglamer, E. (2007). Teftiste yeniden yapılanma. Cagdas Egitim, 32(343), 5-12.

Sonar, I. (2002). Bilgi teknolojisi siniflarinin kullanilma duzeyi. Unpublished master's thesis, Selcuk University, Konya, Turkey.

Turan, S. (2002). Teknolojinin okul yonetiminde etkin kullaniminda egitim yoneticisinin rolu. Egitim Yonetimi, 8(30), 271-281.

Wiles, J. \& Bondi, J. (2000). Supervision: A guide to practice. NJ: Prentice Hall.

Salih Pasa Memisoglu PhD, Assistant Professor of Educational Administration and Supervision, Faculty of Education, Abant Izzet Baysal University, Bolu, Turkey 14280. Email: memisoglus@hotmail.com 